\title{
ZANG LXXXIV TOT XCI VAN DEN NĀGARAKRTĀGAMA.
}

DOOR H. KERN.

De maat hiervan is een soort Krti.

1. Prāpta ng diwaça kaping pādbělas i wijil Çrī-narapati warṇnan | tingkah nira miderr ing ' nāgara marasuk bhūṣaṇa kanakādi| çōbhābhra pinikul ing jampana mahawan lantaran atuntun| mantrī saçiwabhujanggādi nika manganggo dadar angiring ${ }^{2}$ sök || $1 \|$

D. i. "Er worde beschreven hoe op den $14^{\text {den }}$ Z. Maj. de Vorst naar buiten kwam en in de stad rondging getooid met sieraden van goud enz. .Luisterrijk pralend werd hij gedragen in een palankijn, terwijl wegberijders aan beide zijden gingen ten geleide. Mantri's met geleerde geestelijken der Çiwaieten enz., de hun geschonken (kleedij) dragende, vergezelden hem in grooten getale.»

2. Ghūrṇṇa ng paḍahi * mṛdangga truṭika dudū ng çangka tara

$$
\text { yan atri | }
$$

sinrang ni pasělur ing bhaț̣agaṇa manguccāraṇa ng abhiwāda | çloka stuti nira sang parapura de sang nipuṇakawīndra| cihna nrěpati gahan lwī Raghusuta Kṛṣnañjaya (?) subhageng rāt || 2 ||

D. i. "Daverend was 't geluid der feestmuziektrommen ${ }^{4}$; anderzijds weerklonken de schelphoornen helder, opgedrongen ${ }^{5}$ door de lange rij van een troep lofzangers die een begroeting uitspraken; lofgedichten komen uit andere steden van dichter-

1 Gedrukt miderreng, doch de conjunctief is hier niet op zijn plaats.

2 Zoo leze men voor ingiring.

3 Padaha is de lezing van' 't HS.; padahi is mijn conjectuur.

4 Truţika is onvindbaar. Misschien heeft men truţita te lezen, in welk geval men zou kunnen vertalen: „afgebroken door."

$5 \mathrm{Er}$ zal bedoeld wezen: "waarop onmiddellijk volgde." 
vorsten, als blijk dat de Vorst luisterrijk is als Rāma en - (zoo) bemind in de wereld.

Een naam als Kṛșnañjaya is feitelijk ongerijmd. Het zal wel een fout wezen voor Karṇañjaya, Overwinnaar van Karṇa, d. i. Arjuna.

3. Sāmpun nṛpati manek ring maṇimayasinghāsana suminābhra| Çoddhodani sakala lwir nira wahu sangke Jinapada çobhā | byakta trisura Surendrāng umarěk i himbang nira, n-apūja hyang āpan paḍa liněwih bhūsaṇa nika sotan wwang adhika mūlya || 3 ||

D. i.: "Reeds had de Vorst den troon van edelgesteente bestegen, met luister schitterende. Hij leek als Çuddhodhana's zoon (de Buddha) in persoon, zoo even uit het prachtige Jinaverblijf (Buddhahemel) gekomen. Zichtbaar waren de 3 goden ${ }^{1}$ en de heer der Goden (Indra) tegenwoordig aan Zijne zijde, terwijl hij devotie verrichtte. En allen hadden een uitstekend tooisel; geen wonder, dewijl zij hoogaanzienlijke personen waren.

Het dient bijzonder opgemerkt te worden dat de dichter zich Çākyamuni voorstelt als verblijvende in Jinapada, een woord gevormd naar 't model van Wiṣnupada, Wiṣnu's verblijf. Die voorstelling is niet vreemd aan Mahāyānisten, ofschoon ze lijnrecht in strijd is met de oude, rechtzinnige leer.

Ik begrijp níet recht wat de dichter in de twee laatste versregels eigenlijk te kennen geeft. Er kan toch geen sprake wezen van de werkelijke tegenwoordigheid van Indra enz., in eigen persoon! Hoe dan 's mans woorden te verklaren? Wellicht op de volgende wijze. Uit de beschrijving die de Chineesche pelgrim Hiuen Thsang geeft van een groot feest hetwelk Koning Çîlāditya (al. Harșa) bij zekere gelegenheid aanricht, blijkt dat een gouden beeld van den Buddha plechtig op een olifant werd rondgedragen, terwijl de koning zelf, in 't kostuum van Indra, ter linkerzijde een prachtīg zonnescherm ophield, en koning Kumāra van Kāmarūpa (Assam), onder de trekken van den god Brahma, met een witten vliegenwaaier in de hand zich aan den rechter kant hield ${ }^{2}$. Hieruit ziet men, dat hooggeplaatste personen bij een feestelijke gelegenheid den Buddha in effigie vereerden door de rollen op zich te nemen van godheden die den Meester bij diens leven als nederige dienaren hulde plachten

1 D. i. Brahma, Wiṣnu en Çiwa? Onzekerer.

2 Zie Stan. Julien, Voyages des Pèlerins bouddhistes, II, 258. 
te bewijzen. Hun rol bracht mede, dat zij het kostuum der door hen voorgestelde goden aannamen. In ons gedicht neemt de Koning zelf de plaats van den Buddha in, die aan zijne zijde aanzienlijke personen heeft welke gedienstige godheden voorstellen. Wie die personen zijn, wordt niet gezegd. Dit is de eenige verklaring die ik van de alles behalve duidelijke plaats weet te geven. Doch gaan wij verder.

4. Tingkah ni laku nira çrī-nṛpati Pajang sapriya pinakāgra | singhāsana nira sāmpun lěpas inarak ning balagạ̣a kīrṇṇa | mantrī Pajang athawā mantri ri Paguhan rowang ika sapaṇta | lakṣārwuda marasuk bhūṣaṇa saha bhrětya dhwaja pațahādi || 4 ||

D. i.: In den tocht vormde Z. Hoogheid de Vorst van Pajang met zijne geliefde gade de voorhoede. $\mathrm{Zijn}$ troon was reeds vooruit, statig begeleid door een wijdverspreide menigte troepen. De Mantri's van Pajang en de Mantri's van Paguhan, hun gezellen, (volgden) in groepen: lakșa, a rbuda ${ }^{1}$, gekleed in prachtkostuum, met dienaren, vlaggen, trommen enz.»

5. Mangkā nṛpa ri Lasěm sapriya ri wugat lampah ira sabhṛtya | mwang çrī-ṇ̣pa ri Kaḍintěn saỵugala sāmātyabala ri wuntat saçrī çrī-Jīwanapararājñ̄i ri wuri saha bhrětyagạ̣a sabharttā|

çrī-bhūpati paměkas mantrỵ adhika sa Yāwāwani mangiring sök $\|5\|$

D. i.: "En de vorst van Lasěm met zijne vrouw trok daar achter met zijne dienaren, en daarachter $\mathrm{Z}$. Hoogheid de vorst van Kaḍiri met gade, met ministers en leger, met pracht. H. Maj. de opperkoningin van Jiwana (Kahuripan) daarachter met de schare van dienaren, met haar echtgenoot. De overige landsheeren en voorname Mantri's van geheel Javaland volgden in groote menigte.»

6. Ton tang parajana sarsök pěnuh ariwĕg tanpasěla manonton | pinggir nikanang lěbuh ajajar çakața ${ }^{2}$ pinanggung ${ }^{3} \mid$ dwārānapis 4 awawa lwir dhwaja nguniweh panggung ika riněngga |

sök stry anwam atuha dudw ang mangěběk umunggw ing bacingah atimbun $\|6\|$

1 Ik heb deze telwoorden onvertaald gelaten. Zelfs als men aan die getallen een veel geringer waarde toekent dan ze in 't Sankrit hebben, zijn de eijfers van den dichter belachelijk overdreven.

2 Verbeterd uit sakatha.

3 Het vers is niet in orde; er ontbreken drie lettergrepen.

4 Lezing rerdacht en daardoor de woordseheiding onzeker. 
D. i. "Men zag een talrijk publiek, in volte samengeschoold zouder tusschenruimte, toeschouwende. Aan den rand der hoofdstraat (of Alon-alon) stonden op een rij wagens als tribunen ingericht ${ }^{1}$. De deuren - als (?) vlaggen ${ }^{2}$ en de kijktribunes waren versierd. Een menigte jonge en oude vrouwen vulden de plaatsen op het buitenplein bij hoopen.»

7. Buddhinya ḍaraḍaran kapwa suka bangun wāhuwahu manonton tan warṇnan ulah ikeñjing nẹpati kinastryan mijil i wanguntur | wiprādi sira maweh amrětawarakuṇḍyādi wawan ikāpněd | mantrī paraměgět kapwa marěk amụspāñjali parěng asrang || 7 ||

D. i. "Benieuwd in hun geest schepten zij allen evenzeer vermaak alsof zij het nu pas toeschouwden. Wij behoeven niet te beschrijven wat zij deden, toen den volgenden dag de Vorst gehuldigd uitkwam aan den Mangantur. Brahmanen enz. gaven gewijden drank, en sierlijk waren de kruikjes die zij aanboden. Mantri's en notabelen maakten hun opwachting in dichten drom hulde betoonende met aaneengesloten handen.»

\section{ZANG LXXXV.}

In de maat Suwadanā.

1. Tanggal ning Caitra tekang balagaṇa mapulung rahy āhěm apupul | mantrī mwang tạ̣da gusti sahana nguniweh wadwā haji tumūt | milw ang mantry ākuwu mwang juru buyut athawā wwang ring parapurī |

āstām sang kṣatriya mwang wiku haji karuhun sakweh dwijawara || 1 ||

D. i. "Op den dag der nieuwe maan van Caitra " vergaderde het heir en hield gezamentlijk raad. De Mantri's en hoofdofficieren en Gusti's alle: alsook het gevolg des konings, namen er deel aan; alsmede de dorpshonfden en dorpsoudsten en lieden van andere steden, om niet te spreken van de Kșatriya's en koningsmonniken, voorafgegaan door alle voorname Brahmanen.»

De beteekenis van mapulung rahi is mij onbekend. Mis-

1 De zin loopt oogenschijnlijk goed af; toch moet in den oorspronkelijken tekst iets anders gestaan hebben; want de maat is gestoord.

? Onverstaanbaar.

3 Caitra is de eerste lentemaand in 't begin van 't jaar. 
schien is het een uitdrukking die in eigenlijken zin te vergelijken is met onze uitdrukking: "de koppen bij malkaar steken."

Onder de genoemde waardigheidbekleeders zijn er eenige, waarvan 't karakter ons slechts onvolkomen bekend is.

2. Don ing höman ri tan lamlama ni sabala sang çrīnātha ring ulah kapwānūtājar ing Rājakapakapa sadāngkěn Caitra winaca| haywāngambah ri tan lakwa nika maněkěteng wastrādyaraṇa(?) dewaswādinya tātan purugěn ika maran swasthāng pura sadā || 2 ||

D. i.: "Het doel van de beraadslaging was, dat al de troepen des konings in hun gedrag niet hebzuchtig zouden wezen, en dat zij de lessen in 't Rājakapakapa, hetwelk altoos elke Caitramaand wordt voorgelezen, zouden volgen; opdat zij niet een weg zouden betreden die verboden is, terwijl zij zich moeten in acht nemen ${ }^{1}$. Zij mogen zich volstrekt niet vergrijpen aan godeneigendommen enz. ${ }^{2}$, opdat het den staat steeds welga.»

Kapakapa is blijkbaar een soort geschrift. In 't Jav. Wdb. vindt men opgegeven een "Layang Kapakapa», naam van een boek dat gezegd wordt door dien Adipati geschreven te zijn; en Adipati Rājakapakapa is, volgens hetzelfde Wdb. "naam en titel, door Daniswara aan Beggdja gegeven», Daniswara, d. i. Dhaneçwara is welbekend als een naam van Kubera. Blijkbaar is het hier genoemde Rājakapakapa een geschrift uit den Hindutijd en dus zeker wel identisch met het door Prapañca bedoelde.

\section{ZANG LXXXVI.}

In Mandākrāntā.

1. Ākāra rwang dina muwah ikang kāryya kewwan narendra | wwantěn ${ }^{3}$ lor ning pura těgal anāma ng Bubat kaprakāça| çrī-nāthāngkěn mara makahawan swāna ${ }^{*}$ singhāpadudwan| sabhrětyānorakěn iděran atyadbhuta ng wwang manontan || 1 ||

D. i. "Na een tijd van twee dagen was door den Vorst op nieuw voor een feest zorg gedragen. Er is ten Noorden van de stad een veld, bekend onder den naam van Bubat. Z. Maj. de Vorst gaat telkens daarheen, terwijl hij als voertuig gebruikt

1 Wastrādyaraña is corrupt: er ontbreekt één lettergreep. Ik weet geen zeker geneesmiddel. Mogelijk, doch geenszins zeker, is: Wastrā dyaharaña, d. i. "kleederen enz. niet te rooven."

2 Onder enz. versta men, in de eerste plaats, 't eigendom van brahmanen.

3 Conjectuur voor waw wan.

4 De tekst heeft sthāna.

Dl. 69. 
honden en leeuwen die niet met elkaar harmonieeren. Al de dienaren rondom houden die onder bedwang; met de grootste verbazing zien de menschen het aan.»

2. Ndan tingkah ning Bubat araharārddhāratātạ̣ḍěs alwā | madhyakroçākara nika n-amūrwwānutug rājamārgga| madhyakroça kěta pangalornya nutug pinggir ing lwah | kedran de ning bhawana kuwu ning mantri sasök mapaṇța || 2 ||

D. i. "En Bubat doet zich voor als een woeste grond, zeer vlak, niet begroeid, ruim. Een halve Kroça strekt het zich uit Oostwaarts tot aan den koningsweg; meer dan een halve Kroça Noordwaarts tot aan den rand der rivier. Het is rondom omgeven door huizen en optrekken van Mantri's in menigte gegroepeerd.»

3. Bwat-bwat munggw ing těngah aruhur atyadbhutāděgnya çobhā stambhanyākweh inukiran athāparwwa tingkah nikāpněd! skandhāwāre nikața nika kulwan rakět lwir'pure jro | nggwan çrī-naranātha n-dunung i těka ning Caitramāsạ n-pamanggung || 3 ||

D. i. "Verwonderlijk schoon staan daar te midden hooge bouwwerken, waarvan vele zuilen met beeldwerk versierd zijn en met geledingen die er fraai uitzien. Het koninklijk hoofdkwartier in de nabijheid daarvan ten Westen, gelijk de hofburg, is de plaats waarheen de Vorst zich begeeft wanneer de maand Caitra gekomen is, als wanneer hij op een Panggung ${ }^{1}$ stijgt.

\section{ZANG LXXXVII.}

De maat is Çikharinîi.

1. Pratingkah ning panggung majajar angalor paçcimamuka| ri saṇḍing lor mwang dakṣiṇa haji parakṣatriya pinik| sumantrī dharmmādhyakșa kěta ng umarěp wetan atatā| harěpnyārddhālwā lwir nika sadawatā ning lěbuh agöng || 1 ||

D. i. "De tribunes stonden op een rij naar 't Noorden, met de voorzijde in 't Westen. Aan de Noord- en Zuidzijde waren de koning en uitgelezen Kṣatriya's. De hoofdmantri's en de Dharmādhyakșa zaten in rangorde met het aangezicht naar 't Oosten gericht, Het daarvoorliggende is zeer ruim, zoodat het zich uitstrekt over de geheele lengte van den grooten weg.»

1 Panggung is een op hooge stijlen rustende toren of koepel, of een tribune, om naar een vermakelijkheid te kijken. 
2. Rikā nggwan çrī-nātha n-parahita maweh netrawiṣaya | hanan prang tanding prang pupuh ikang atombokan ${ }^{1}$ inadu | akanjjar len prěp mwang matalitali moghāngdani ${ }^{2}$ suka| hanan pat mwang trīkang dina lawas irā çīghra n'umulih || 2 || D. i. "Dáár was het dat Z. Maj. de Vorsf aan 't algemeen een weldaad bewees door het iets te geven wat een oogenlust was. Er waren er die een wedstrijd hielden; met strijdhamers vochten; (anderen) die tegen elkander gesteld werden om te botsen; die met dolken vochten en met vuisten, en met touwen (lasso's?); wat niet naliet vermaak te wekken. Het duurde soms vier of drie dagen. Daarna keerde hij huiswaarts.»

3. Ryy ${ }^{3}$ ulih çrī-nāthekang Bubat sěpi panggungnya dinawut | samangkā tang prang-taṇdingan inura mangkin sukakara| ri panglwang ing Caitra nrěpati n-umiwö çrāma sahana| wineh wastra mwang bhojana paḍa suka n-mamwit umulih || 3 ||

D. i. "Na den terugkeer van Z. Maj. den Vorst was Bubat verlaten en werden de tribunes opgeruimd. Toen werden de wedstrijden ontbonden, hetgeen nog meer vreugde veroorzaakte ${ }^{4}$. In de tweede maandhelft van Caitra onthaalde de Vorst alle kampioenen(?), die, begiftigd werden met kleeding en voedsel, verheugd afscheid namen en huiswaarts keerden.»

\section{ZANG LXXXVIII.}

In Madraka-maat.

1. Salwir ikang buyut wadana teki tanwawang umantuk amwit $\mathrm{i}$ dalěm |

Āryya Raṇādhikāra dinulur nikādhipati ring eñjing humarěk| Āryya Mahādhikārạ juru pañca tạ̣ḍa pinakādi ring padělěgan | rowang ika n-paḍāmwit i sẹ̆ạang nareçwarān tinangkil apupul ||1 ||

D. i. " $\mathrm{Al}$ de dorpsoudsten (en) Wadana's keerden weldra huiswaarts na afscheid genomen te hebben van 't Hof. Ārya Raṇādhikāra, vergezeld van den Adhipati, maakte 's morgens zijn opwachting. Ārya Mahādhikāra, de dorpshoofden, de 5 ouderlingen (van het dorpsbestuur), de hoofdbeambten in de Padělěgan, waren hun gezellen bij 't afscheidnemen toen de Koning met gemalin audientie verleende.»

1 Gissing voor atembokkan.

2 De tekst heeft een overtollig $\mathrm{ni}$.

$s$ Gedrukt. Yyulih.

4 Dit is mij niet recht duidelijk. 
$\mathrm{Bij}$ 't vertalen der titels heb $\mathrm{l} \mathrm{k}$ mij met gissingen moeten behelpen. Mijn vertolking van pañcatanda berust op de veronderstelling dat het een svnoniem is van Nieuwj. pancakaki, de leden van 't dorpsbestuur (eig. de 5 Ouden), in verband met het feit dat in het Tagalog taṇáa de beteekenis heeft van "Oudste».

De beteekenis van padělěgan is onbekend, maar zóóveei is duidelijk dat het samenhangt met pandělěgan, volgens Jav. Wdb. onder dělěg: naam van een soort van beambten in den ouden tijd.

2. Ngkā n-pawuwus nareçwara ri Wěngkěr ojar i parāndyanādi wadana |

he ${ }^{1}$ kita haywa tan tuhu susatyabhakty asih aniwya nātha ri haji |

sthitya kiteng kāweçyan i singāngdane ${ }^{2}$ hajěnga ning prạdeça ya gěngěn

setu ḍamārgga waṇdira gṛhādi salwir ikanang sukīrtti pahayun || 2 ||

D. i. "Daar nam de vorst van Wěngkěr 't woord. Hij sprak tot de Edele heeren ${ }^{3}$ enz. en Wadana's: O, gij lieden! wacht u om niet oprechtelijk zeer waarachtiglijk trouw en met liefde den Koning als uw heer te dienen! Weest ferm in uw landschap om $\mathrm{u}$ toe te leggen op alles wat strekken kan om het heil der streek te bevorderen! Draagt zorg voor bruggen, groote wegen, Waringins, huizen en al de gewijde monumenten!»

8. Mukya nikang gagā sawah asing tinandur ika wṛddhya rakṣan amĕrĕn |

yāwat ikang lěmah pinakarāmakěn pagehha tanpadadya waluha (?) |

hetu nikang kulīna tan atuṇdung ng aparadeça ${ }^{+}$yan pataruka $\mid$ nang pratiguṇḍalanya tutěn ri gönga nikanang pradeça n-usirěn || 3 ||

D. i. "De voornaamste hoogvelden en sawahs, al wat geplant wordt, moge gedijen. worde beschermd en gekoesterd! Voor

1 Gedrukt e.

2 In den tekst foutief singāng dene.

3 Parāndyan bestaat uit para + andyan, waarvoor Z. 89, 3 handyan heeft. Het is m.i. een bijvorm van hadyan. Vgl. Malagasi andriana.

4 Conjektuur voor a maradeça. 
zoover de grond strekt om ingedijkt (?) te worden, worde die bevestigd, opdat het niet een doorbraak' ten gevolge hebbe, opdat de huislieden niet naar andere oorden verjaagd werden om zich daar te vestigen; in zoo'n geval heeft men het koninklijk rescript ${ }^{2}$ te volgen bij (de bepalîng van) de grootle van 't gebied waarheen men de toevlucht wil zoeken.»

4. Çrī-Kṛtawarddhaneçwara hamaywanī kagěngan ing pradeça gawayěn |

ndan wilangěn mahānasa rika ${ }^{3}$ pramāda nika ring pějah çaçi sadā mịilwa ta yomapekṣa hana ning durātmaka makādya añidra lawana |

wṛddhya ni dṛwya sang prabhu phalanya sādhana nirān rumakșa bhuwana $\|4\|$

D. i. "Z. Hoogh. Kṛtawardhana * verordent hoe groot het te bebouwen dorpsgebied zal wezen, en de haardsteden ${ }^{5}$ moeten geteld (d. i. opgeschreven) worden bij nalatigheid op den laatste van elke maand. Tevens zal hij acht geven op de boosdoeners, te beginnen met de overspelers(?); (en toezien) dat de inkomsten des Konings toenemen, die dienen als middelen voor Hem, om het land te beschermen.»

5. Çrī-ṇ̣pa Tiktawilwanagareçwarāngūpasama n-sumantěn ${ }^{6}$ ammuwus |

somya $^{7}$ ngaranya rakwa kadadinya teki katěkanya haywa wișama $\left.\right|^{8}$

yan hana rājakāryya palawang makādi nika tan hana n-lěwata ${ }^{9}$ | yan pasěgěh muwah wruh anahā swadeha nikạ somya ${ }^{10}$ laksạ̣a gěgěn || $\overline{||}$

D. i. "Z. Maj. de Vorst van de stad Majapahit, de alleenheerscher, deed hem ophouden, terwijl hij 't woord nam.

$1 \mathrm{Ik}$ gis dat voor waluha gelezen moet worden walaha, conjunctief van walah (wělah), volgens Jav. Wdb. synoniem van pĕcah.

2 De beteekenis van dit woord is moeielijk nauwkeurig te bepalen; vgl. vs. 1 van den volgenden Zang.

3 Conjectuur voor rikan.

4 De vader des Konings.

${ }^{5} \mathrm{Skr}$. mahānasa is "keuken"; hier blijkbaar vertaling van d̦apur.

6 Gedrukt sumintěn.

7 Conjectuur voor sāmya.

8 Conjectuur voor wis a m ma.

${ }^{9}$ Gedrukt nl wata.

10 Conjectuur voor sāmya. 
"Wiens wezen is wat men noemt "saumya» (d. i. Latijnsch faustus), moet men niet bemoeilijken wanneer hij (tot ons) komt. Als er bij den koning dienst gedaan wordt, in de eerste plaats door deurbewaarders, moet het niet voorkomen dat (iemand die toegang verzoekt) afgewezen wordt(?). Als hij bij 't onthaal verder weet zich zelf schroomvallig in acht te nemen, wordt het gehouden voor een gunstig teeken.»

\section{ZANG LXXXIX.}

De maat is een species van Kṛti. In dezelfde maat is Bhārata-yuddha, Zang VI, gedicht.

1. Mwang rasa ning pratiguṇḍala pangaděg irebu hajīka tutěn | eñjinga yan padangāngratěngana sabhinukti nikān pasěgěh | yan hana mūrkka tikang siněgěhan agawe lara sāhasika | tut sasinambut ${ }^{1}$ ikā sing awaka nika tājarakěn ri kami || $1 \|$ D. i. "En de inhoud van het koninklijk rescript onder de regeering van de Moeder des Konings worde gevolgd. Des ochtends moet men koken en gaar maken al wat genuttigd wordt door hem dien men onthaalt. Indien soms de onthaalde zoo dwaas is dat hij leed veroorzaakt, brutaal is, dan behoort al wat door hem ondernomen wordt, van welken aard het ook zij, aan ons bericht te worden.»

2. Āpan ikang pura len swawișaya kadi singha lawan gahana| yan rusaka ng thani milwa ng akurang upajīwa tikang nagara| yan taya bhṛtyaa katon waya nika paranūṣa těkāngrěwěka| hetu nikān paḍa rakșan apagěha kalih phala ning mawuwus || 2 ||

D. i. "Want de hoofdstad en 't daarbij behoorende gebied is als de leeuw en 't dichte woud. Als het bouwland verwust is, zal het ook der hoofdstad aan levensonderhoud ontbreken. Als er geen dienstdoenden (d. i. weerbare manschappen) zijn, is het duidelijk dat er andere eilanden zijn die een invasie zullen wagen. Daarom bescherme men beide, opdat ze verzekerd zijn, als vrucht (mijner) rede.»

3. Nāhan ujar nira ring para wadana sahur nika sapraṇata| eka hatur nika tan salah anuta saling naranātha kabeh| mantry upapatty anangkil ${ }^{2}$ athaca parahadyan ateki marěk | țog ${ }^{3}$ tumibāng ghațita traya panaḍah ireky apupul caritan .|| 3 ||

\footnotetext{
1 Gedrukt sin ambat,

2 Gedrukt anangkal.

3 Verbeterd uit thog. Vgl. Jav. tuk.
} 
D. i. "Zoo sprak Hij tot de Wadana's. Zij antwoordden, nederig gebogen: eenstemmig verklaarden zij, zonder falen al wat de Vorst gezegd had te zullen opvolgen. De Mantri's en Upapatti's maakten hun opwachtlng, alsook de Edele heeren aldaar. Tik, de klok sloeg drie.

Wij zullen nu hun gezamenlijken maaltijd beschrijven,»

4. Uttarapūrwwa witāna ${ }^{1}$ kahanan ira çobha rinangga huwus | ring tri witāna matūt padu para ${ }^{2}$ wadanādy apupul tinatā | prāpta tikang taḍah uttama wawan ika sarwwa suwarṇnamaya | çīghra tikang humaręp-harěpakěn atitah ri haręp ṇ̣pati $\|4\|$

D. i. "De feesttent ${ }^{3}$ in 't Noordoosten, waar hun plaats was, was prachtig versierd geworden. In drie feesttenten langs de hoeken waren de Wadana's enz. bijeen geschaard. De kostelijkste spijzen werden aangebracht; de presenteerbakken waren alle van goud. Fluks schaarden degenen die (de spijzen) aldoor voorzetten, zich voor den Vorst.»

5. Lwir ni taḍah nira meșa mahiṣa wihaga mrĕga wök madhupa | mīna lawan tikang aṇ̣a haja ring aji lokapurāṇa tinūt | çwāna kara krimi mūṣika hilahila len wiyungng alpa dahat | çatrw awamāna hurip-kṣaya cala nika rakwa yadi purugěn || 5 ||

D. i. "De spijzen bestonden uit (vleesch van) schapen, buffels, vogels, herten, uit honig, visch en eieren, geiten, volgens het godsdienstig voorschrift der oudheid ${ }^{4}$. Verboden zijn honden, ezels, wormen, muizen, en nietswaardige kikvorschen. Verachting bij den vijand (of: vijanden, verachting), levensverlies, beschimping komt er van, als men ('t voorschrift) overtreedt.»

De opsomming welke in deze strofe gegeven wordt van geoorloofde en verboden spijzen is wel niet volledig, maar anders geheel in overeenstemming met de voorschriften der Indische wetboeken. Ze geeft tevens eenig denkbeeld van de spijzen die bij gastmalen opgedischt werden. Van vegetarisch dieet is geen sprake. Een uitvoerige beschrijving van een maaltijd wordt gegeven in den volgenden Zang.

- In den tekst witanna.

2 Gedrukt para.

3 Mogelijk 't meervoud bedoeld.

4 D. i. de Indische wetboeken, o. a. Manu V, 11 vgg. 


\section{ZANG XC.}

De maat hiervan heet Praharṣaṇī.

1. Prāpta ng bhojana makadon rikang wwang akweh | sangkěp sarwwarajasa ${ }^{1}$ bhojananya çobhā matsyāsangkya sahana ring darat mwang ing wwai | rāprěp drāk rumawuh anūt kramānuwartta || 1 ||

D. i. "De spijzen, bestemd voor 't algemeen, werden aangebraeht. Volledig waren de prachtige spijzen van allerlei smaak(?); ontelbaar allerlei visschen van 't land en van 't water ${ }^{2}$. Roef, roef! gezwind kwamen ze (d. i. werden aangebracht) achtereenvolgens.»

2. Maṇụūka krimi kara mūṣika çṛāla|

kweh sakterika ${ }^{3}$ winahan tamahnya tușța|

deni wwang nika dudu ring sadeçadeça |

sāmběknyeki tinuwuk dumeh ya tușțā || 2 ||

D. i. "Kikvorschen, wormen, ezels, muizen en honden, aan velen die daaraan gehecht waren werd toegegeven, zoodat hun vraatzucht (kwade neiging) bevredigd werd. Omdat de menschen verschillen naar gelang van de verschillende streken, wordt denzulken toegegeven naar hun zin, opdat zij tevreden zullen wezen.»

Uit het hier gezegde blijkt, dat velen onder 't gemeene volk zich niet aan de spijsvoorschriften der wetboeken stoorden.

3. Lwir ning pāna surasa tan pěgat mawantu | twak ny $\bar{u}$ twak siwalan arak ${ }^{4}$ hano kilang brĕm | mwang tampo sing adhika tang hane harěp sök | sarwwāmās wawan ika dudw anekawarṇna || 3 ||

D. i. "Soorten van lekkere dranken volgden zonder ophouden op elkaar: kokospalwijn, toddy, arak, sap van de Arènpalm ${ }^{5}$,

1 Onzekere conjectuur voor 't onmogelijke rājatha van den gedrukten tekst.

2 Wat met "landvisschen" bedoeld wordt, is moeielijk te zeggen. Alleen zij opgemerkt dat de Indiërs den term matsya toepassen op dieren welke in 't geheel geen visschen zijn, zooals kuḍyamatsya, huishagedis.

${ }^{3}$ In den tekst çakterika.

4 Gedrukt harak.

${ }^{5}$ Of arak (gegiste drank) van de Arènpalm. 
Kilang ${ }^{1}$, Brĕm ${ }^{2}$ en Tape. Die (dranken) zijn de voornaamste van die in menigte voorgezet (opgediend) werden. De schalen waren alle van goud of anders veelkleurig (of: veelsoortig).

4. Rombeh mwang guci tikanang prakīrṇṇa lumrā |

arddhākweh sajĕng ika dhātu anekawarṇṇa|

tanpāntya ng larih aliwěr bangun wway adrěs |

sāmběknyānggapan umutah wuneh byamoha || 4 ||

D. i. "Kannen(?) en aarden kruiken stonden er overal verspreid. $Z$ ij bevatten zeer veel bedwelmende dranken en waren van verschillende grondstoffen. Zonder einde ging de (ingeschonken) drank rond alsof het stroomend water was. Volgens neiging te gretig (drinkende), braakten (sommigen); anderen verloren hun bezinning.»

5. Prahprah nṛpati n-aweh kasukan pamukti |

yan wwang sakta paḍa pinarān larihnya limpad|

tan dadyāmidhi ring alah tělas kasěngkwan |

ring wwang māna lagi wěrö werrö ginuywan $\| 5$ \|

D. i. «De Koning placht, als hij een feestmaal gaf, te vragen of men drinkebroers aantrof, wier beschonkenheid te veel gevorderd was. Het zou niet aangaan, degenen die al te zeer beneveld waren, uit te noodigen (zich bij hem te zetten). Wat overmoedige(?) menschen betreft welke steeds ${ }^{3}$ dronken zijn, die worden uitgelachen.»

6. Rāmya ng gītada pangidung nikān maganti |

kīrtti çrī-nṛpati linakwakěnya n-angras |

mangkin tușța sang anginum samenake twas |

sowenyālah awěkasan maguywaguywan || 6 ||

D. i. "Lustig (aan te hooren) waren de zangers die een beurtzang aanhieven ${ }^{4}$. De roem van Z. Maj. den Vorst werd door hen bezongen, hartverrukkend. Hoe langer hoe meer waren de drinkenden vergenoegd, zoo zeer als men van harte blijde kan wezen. Nadat het lang genoeg geduurd had, eindigde men met allerlei schertsen te maken.»

\footnotetext{
1 Tegenwoordig verstaat men daaronder verdikt suikerrietsap, stroop; volgens K.B.Wdb. is het een bedwelmende drank.

2 Een zeer bedwelmende uit rijst bereide drank. Het woord is merkwaardig overoud, daar 't Formosaansch borom hetzelfde beteekent.

3 Lagi kon ook "pas" beteekenen.

4 $\mathrm{Wij}_{\mathrm{ij}}$ zouden ons anders uitdrukken en zeggen: Zangers hieven lustig een beurtzang aan.
} 
Het zonderlinge woord gitada, dat ook in st. 5 van den volgenden Zang voorkomt, beteekent letterlijk "een gezang gevende», doch komt in 't Skr., hoewel de bestanddeelen der samenstelling Skr. zijn, niet voor. Denkelijk zijn degenen die "een gezang (ten beste) geven» personen uit het gezelschap, welke, zonder zangers van beroep te wezen, door 't zingen van liedjes een bijdrage leveren tot de algemeene vroolijkheid.

\section{ZANG XCI.}

In de maat Wamçapatrapatita.

1. Jurw iy angin cucud saha buyut nikana macěmacěh | prāpta manṛtta ring çwara(?) n-umambili sadulur ikā | solahulah nikāmuhara guyw anukani lumihat | hetu nikān wineh wasana tang parawadana kabeh $\|1\|$

D. i. "Juru's iy angin ', grappenmakers met hun hoofden makkten groote pret(?). Zij kwamen dansende, terwijl ze hun genooten kozen. $\mathrm{Al}$ hun doen verwekte gelach en gaf den toeschouwers genoegen, weshalve alle Wadana's met kleederen begiftigd wetden.»

In de vertaling is uitgelaten de vertolking van de verdachte lezing ring çwara. Misschien heeft men te lezen ring swara en is bedoeld "op bevel». Zeer onzeker.

2. Ri wěkasan kinon marěka milu alariha ri harěp |

mantry upapatti kapwa dinulurnya n-alarih angidung |

manghuri kaṇdamohi pangidung ira titir inalěm |

çrī-nṛpati n-widagdha manulanggapi rěsěp alangö || 2 ||

D. i. "Ten slotte werden zij uitgenoodigd om voor den Vorst te komen en mede zich in te schenken. De Mantri's en Upapatti's (of de Upapatti genaamde Mantri's) van hen vergezeld schonken zich in en zongen een liedje. Het gezang van den Anghuri en Kaṇdamohi werd herhaaldelijk toegejuicht. Z. Maj. de Koning, die ervaren is in de kunst, deed mede aan de verrukkelijke uiting van blij gevoel.»

Kaṇdamohi, in K.B.Wdb. Kaṇḍamuhi, is hetzelfde als Nieuwjav. o ṇ d a mohi, volgens Jav. Wdb. «benaming van een mannelijken bediende in de Kraton in vroeger tijd.» Een «be-

1 Wat voor lieden zoo heeten, heb ik niet kunnen opsporen. Mogelijk is er eenig verband tusschen de uitdrukking in den tekst en Jav. anginan, een benaming van 't beheer (reh) der Goenoengs, doch welk? 
diende» is hij zeker niet, maar een voornaam beambte, zoo als op te maken is uit de aanhaling in KBWdb. onder dharmmādhyakșa, waar hij betiteld wordt met sang āryya. Anghuri is zeker wel hetzelfde als manghuri, zie KBWdb.i.v.

3. Gïta narendra manghělāngdani jĕngěr angani |

mrak mañawuwwang ing padapa tulya nika ring alangö| lwir madhu len gula drawa rinok ring amanis añeñer| wangça maghāsa tulya nika ring rěs angungěr i hati || $3 \|$

D. i. "Het verrukkelijke gezang van den Vorst verwekte (hart) treffende bewondering. Het geleek in 't liefelijke als het kweelen van een pauw op een boom; als honig en gesmolten suiker gemengd, in 't aangenaam zoete; als riet met een schurend geluid in aandoenlijkheid, hartroerend ${ }^{1}$.»

4. Āryya Raṇādhikāra lali yan haturi narapati | āryya Mahādhikāra ta dulur nika parěng amuwus | an parahandyan āpti mihate sịra n-arakěrakět | $\bar{a}$ juga ling nirātěhěr umantuk adadadadakan $\|4\|$

D. i. "Ārya Raṇādhikāra vergat den Koning een verzoek te doen ${ }^{2}$ doch Ārya Mahādhikāra, zijn metgezel, zeide dat de Edellieden hem wenschten te zien terwijl Hij een maskerspel vertooning gaf. "Ja!» zeide $\mathrm{Hij}$ maar ${ }^{3}$. Onmiddellijk keerde hij (Mahādhikāra) terug en maakte haastig de noodige toebereidselen.»

5. Çrī-Kṛtawarddhaneçwara mamañjaki sira rumuhun | ngkāna rikang witāna ri těngah rinacana dinadak | çori nireki gîtada lawan těkěs ira rahajěng | sotan ulah karāmyan ikanang guyu juga winangun || 5 ||

D. i. Z. Hoogh. Kṛtawardhana begon met als dilettant de gamělan te bespelen in de feesttent, die in 't midden geïmproviseerd in orde gebracht werd. De koningin zong een lied met een mooie těk $\breve{s}+$ op. Door die manier van doen tot amusement, werd vroolijkheid gewekt.»

Bij de vertaling van mamañjaki heb ik mij laten leiden

1 De vertaling van 't onvindbare angungĕr berust louter op gissing.

2 Naar ik veronderstel, doordat hij zoo weggesleept was door 't schoone gezang des Konings.

$3 \overline{\mathrm{A}}$ neem ik hier in den zin van Skr. $\overline{\mathrm{a}} \mathrm{m}$; misschien is dan ook āng de warē lezing.

4Tĕkĕs is volgens Jav. Wdb.: „een soort van pruik, hooge muts van gekroesd haar, een hoofdsieraad bij het Topèngspel. 
door 't Sundaneesch taalgebruik, want wat in KBWdb. onder pa ñ a k gegeven wordt, is onbruikbaar. Intusschen zou ik geneigd zijn, afgaande op de beteekenissen van pa ñjak, te gelooven dat mamañjaki den zin heeft van "als regisseur optreden.» In allen gevalle moet wat 's Konings vader doet dienen als inleiding tot de volgende mimische vertooningen.

6. Ndāluwaran sireki ri ḍatang narapati n-angaděg | gīta nirānyat angdani girahyasen ing umulat| çori ${ }^{1}$ nireki suçrama nirukti lituhayu wagę | gīta nikānghiribhirib aweh rěsěpan ing umulat || 6 ||

D. i. "Er werd door haar uitgescheiden bij de komst van den Koning, die opgestaan was. Een ander gezang van haar bracht de toeschouwers in geestverrukking. De koningin was flink, onberispelijk(?) schoon van voorkomen en knap. Het mimisch gezang gaf den toeschouwers behagen.»

De vertaling van deze strofe is, vooral door de dubbelzinnigheid van de genitieven nira en nireko, onzeker.

7. Çrī-naranātha tansipi wagus nira tělas arasuk| aṣța těkěs nireki n-upabhāryya rahayu sawala | tus ning amātyawangça wicakṣaṇa tětěs ing ulah | hetu nirānpabañal anibākěn ucapan angěne || 7 ||

D. i. "Z. Maj. de Vorst had zich met niet geringe handigheid gekostumeerd. Acht was 't getal van těkěs, schoon, die hij - , afstammelingen van ministersfamiliën, verstandig, door en door wetende hoe zich te gedragen. Daarom makten zij grappen en lieten treffende gezegden vallen.»

Ook in deze verzen is veel duisters. Upabhāryya is gevormd uit Skr. bestanddeelen, maar als woord van elders onbekend. Misschien beteekent het "medespeler» of "helper». De beteekenis van sawala is hier niet te bepalen. $\mathrm{Bañal}$, hoewel nergens anders voorkomende, kan niet anders zijn dan een andere vorm van bañol. - Těkěs beschouw ik hier als een elliptische uitdrukking voor "iemand die met een těkěs getooid is», evenals wij spreken van "een masker» en daarmee bedoelen «een gemaskerde. - Ondanks onzekerheid op ondergeschikte punten, is het duidelijk dat verhaaln wordt hoe Hayam Wuruk, met acht jongelieden van aanzienlijken huize als tooneelspeler

\footnotetext{
1 Conjectuur voor ço ra.
} 
optreedt. Dit bevestigt wat de Pararaton! omtrent Hayam Wuruk als Dalang en als liefhebber-tooneelspeler in kluchten vermeldt.

8. Nang nawanātya ₹ kapwa tinapak nira tinewèkakèn | hāsya makādi tanpęgat " ikang guyu parěng asělur| mwang karunā mangun tangis aweh sèkel apuhara luh | hetu nikang tumon paḍa kamānușan angènangèn || 8 ||

D. i. Zoo dan - - - - Een klucht vormde het begin; onafgebroken duurde 't gelach al voort. En medelijden verwekte geween, veroorzaakte een droefheid die tranen ontlokte, doordat de toeschouwers alle geroerd waren in hun gemoed.

Den eersten versregel heb ik onvertaald gelaten, dewijl ik uit het verband niet kan opmaken wat bedoeld is met tinapak en tinew ekaken. Onduidelijk is ook nawa nătya. Dit zou kunnen beteekenen "negen tooneelspelers", doch zulks is niet zeker. Zeer zonderling is ook de plotselinge overgang van den tweeden en derden versregel, ofschoon de twee laatste regels anders duidelijk genoeg zijn. De voorstelling begon - zóó althans schijnt het - met een boertig stuk, om gevolgd te worden door tooneelen van aandoenlijken aard.

9. Singhit ing arkka lingsir irikā nṛpati n-atělasan | ngkā parahandyan amwit umusap ri padatala haji |

ling nika mukta pāpa sinungan suka kadi tanirāt| tan wuwusěn stutinỳa haji sampun umulih i dalěm || 9 ||

D. i. «De zon neigde ten Westen. Toen maakte de Vorst een einde (aan 't feest). Alsdan namen de Edellieden hun afscheid met 's Konings voetzolen te vegen; in 't bewustzijn dat zij zondenvrij ${ }^{4}$ waren, werden zij vervuld van een onuitsprekelijk gevoel. Wij zullen niet spreken over den lof dien de Koning ontving, toen hij in zijn paleis was teruggekeerd.»

Niettegenstaande het vele dat in de beschrijving van 't feestmaal en de daarop volgende tooneelvertooning niet zoo duidelijk is als wij wel zouden wenschen, levert ze toch een belangrijke bijdrage tot onze kennis van de wijze waarop aan 't hof van Hayam Wuruk feest werd gevierd, alsook van zijne jovialiteit en kunstzin als liefhebber van tooneelvertooningen, waarbij hij zelf een rol vervulde.

I Blz. 27, en 118.

2 Gedrukt nātya.

3 In den tekst pat.

4D. i. dat zij „hun plicht gedaan hadden". 